\title{
Visual Representations Analysis of Senior High School Biology Textbooks About Plants' Structure and Function
}

\author{
Riani K. Utami ${ }^{1, *}$ Agung W. Subiantoro ${ }^{2}$ \\ ${ }^{1}$ Biology Education, Postgraduate Program, Yogyakarta State University, Jl. Colombo No. 1, Karang Malang, \\ Yogyakarta, 55281, Indonesia \\ ${ }^{2}$ Biology Education, Faculty of Mathematics and Natural Science, Yogyakarta State University, Jl. Colombo No. 1, \\ Karang Malang, Yogyakarta, 55281, Indonesia \\ ${ }^{*}$ Corresponding author. Email: rianiken.2018@student.uny.ac.id
}

\begin{abstract}
This article's purpose is to find out the features of visual representations used in biology textbook about plant tissues structure and function. There were three biology textbooks analysed in this study. Those textbooks are published and used in High School biology classroom based on the current curriculum. The analysis was carried out towards two aspects, including the function of visual representation and its modes categories by identifying and comparing two aspects of the visual representation in the textbooks selected. Based on the analysis, it was included that by its functions, explanatory, illustrative, and complementary representations were likely more occurred in the textbook B. While, the function of decorative was exist in the textbook A and B. By its category, textbook A and C have higher value in table, network, and diagram, while textbook B has higher value only in category photo-realistic picture.
\end{abstract}

Keywords: biology textbook, plant tissue, visual representation.

\section{INTRODUCTION}

Representation is one of tool to increase communication ability, interpretations, and problem solving for students. Representation makes difficult problems or phenomena become easier to understand [1]. Integration of visual representation with text in textbook give more integrated explanation. Using visual representation in textbook is not only provides comprehension about phenomenon and scientific concept, but also creates collective interpretation [2].

Visual representation may have many meanings. There are four aspects of visual representation based on its function. They are decorative, illustrative, explanatory, and complementary. Decorative aspect, if the visual that showed has information which doesn't relate with the text. Illustrative aspect, if the visual that showed explain an object or phenomenon based on text, but there's not another information or additional information. If the visual is equipped with additional information which support another visual and based on the text, it is called explanatory aspect. Last, complementary aspect, if the visual that showed is supporting image or complement that has additional information but it doesn't show in the main text [3].

According to [4] the use of visual representation is limited to what has been designed by experts, so that students tend to understand existing visual representations. Indonesia and Melanesia also use the representation that was design by experts such as in Australia, but students' ability in visual representation linked with experiences and culture because of the limit of resources for representation, props, and formal language [5].

According to [6], biology textbooks in Indonesia have disadvantages compared to other countries such as the UK, Malaysia, and Singapore. The illustrations shown in textbooks in Indonesia are less interesting because most of them are colorless, the material provided is not detailed, the material developed from daily life is small, and the questions given are less developed to improve students' abilities in analyzing and answering questions.

Representation in studying biology especially in biology textbook can be shown in picture, diagram, 
graph, etc. Using visualization in learning plays an important role to give a positive feedback for constructing the right concept, so that the learning purposes can be achieved. Therefore, choosing pictures that showed in biology textbooks must be appropriate, clear, and relate with subject matter so there is no wrong interpretation. Wrong visualization in biology textbook can make misconception and affect student's achievement [7].

Concerning of learning material focused in this article is plant's structure and function. This learning material is listed on the Indonesian curriculum. This learning material have many difficult terms which need to remember and students cannot imagine like what the structure and function of plant tissue. Learning with difficult object or invisible object will affect student's learning outcomes [8].

Plant tissue structure material is the hardest subject matter for students to learn. This material has limitations when learned in class because its size is very small and cannot be directly observed. The material has given by teacher verbally and pictures that support learning is unclear. That's making students become bored and out of focus when learning activities in class [9]

Based on research [10] this material is difficult to understand by students. It shown by the value that does not reach the minimum score of criteria standard (Kriteria Ketuntasan Minimal or KKM in Indonesian). Some problems that identified are students have difficulty in understanding the structure of plant tissue, the function of plant tissue, and the relationship between structure and function of plant tissue. Student who has difficulty understanding the structure of plant tissues will have problem in understanding the function of plant tissue. Therefore, students get trouble to reach the minimum score of criteria standard.

The structure and function of plant's tissue is one of learning materials which have high difficulty, a lot of materials, and not interesting, so that students don't like this learning materials. Other than that, the objects are microscopic. As a result, students have low mastery of concepts. Therefore, right learning strategy is needed so that it can make student more interest and increase mastery of concepts [11]. For increase student's memory, variance in learning with auditioning picture, chart, and colorful decorations are needed [12].

In Indonesia, some studies about visual representation in biology textbook have been done. Based on research by [13] in learning material cell in three samples of biology textbooks that each textbook have shown the right visual representations because they have been matched with cell concept. Three samples of biology textbooks have right relation between visual representations with reality. Function of visual representation in textbooks that mostly showed is illustrative. Another research [7] used seven samples of biology textbooks. Visual representation that was found in textbooks mostly used picture than diagram. The relation between visual representation with real life is appropiate and visual representation that showed have function as example overall. Based on the studies, visual representation is an important lead in biology textbook.

Based on the background, the research question in this study is: how the feature of visual representations of biology textbook in the topic of plant tissues structure and function? The purpose of this research is to the feature of visual representations used in biology textbook in the topic of plant tissues structure and function.

\section{RESEARCH METHOD}

The textbooks used in this study are biology textbook grade XI from three different publisher including biology textbook from Intan Pariwara publisher (coded A) [14], the concept and applying biology textbook from Bailmu publisher (coded B) [15], and student's biology book from Erlangga publisher (coded C) [16]. These textbooks are generally used by Senior High School students in Indonesia. Textbooks are biology textbook which easy to get and had used by students from different school. According to [3] the analysis of comparing visual representation based on its function are decorative, illustrative, explanatory, and complementary. Definitions from each visual representation based on its function are in table 1. as follows:

Table 1. Definitions of visual representation based on its function.

\begin{tabular}{|c|l|}
\hline $\begin{array}{l}\text { Visual } \\
\text { Representation } \\
\text { Based on Its } \\
\text { Function }\end{array}$ & Operational Definition \\
\hline Decorative & $\begin{array}{l}\text { Photo or picture that showed } \\
\text { is not related with the text or } \\
\text { description }\end{array}$ \\
\hline Illustrative & $\begin{array}{l}\text { Photo or picture that showed } \\
\text { is not given additional } \\
\text { information or another } \\
\text { information and just explain } \\
\text { an object or phenomenon } \\
\text { based on text }\end{array}$ \\
\hline Explanatory & $\begin{array}{l}\text { Photo or picture that showed } \\
\text { is given additional information } \\
\text { or another information about } \\
\text { the object based on text }\end{array}$ \\
\hline Complementary & $\begin{array}{l}\text { Photo or picture that showed } \\
\text { have another information but } \\
\text { there is not in the text }\end{array}$ \\
\hline
\end{tabular}

The analysis is continued with analysis of visual representation by categories by LaDue, et al [17]. Visual 
representation by categories are showed in table 2 . as

follows:

Table 2. Visual representation's categories

\begin{tabular}{|c|c|}
\hline $\begin{array}{l}\text { Visual Representation's } \\
\text { Category }\end{array}$ & Operational Definition \\
\hline Graph & $\begin{array}{l}\text { Information is given through graph and object's position which learned in line, bar, } \\
\text { pie, or histogram }\end{array}$ \\
\hline Table & $\begin{array}{l}\text { Arrangement or combination of numbers, words, sign which have information } \\
\text { about facts }\end{array}$ \\
\hline Time chart & Data presentation showed temporarily in graph \\
\hline Network & $\begin{array}{l}\text { Network charts are charts that can show the relation between element and } \\
\text { accompanied by symbols which give the information about presence of the } \\
\text { element. Elements are adapted in line, pointer, or similarity }\end{array}$ \\
\hline Diagram & Static description that showed object's dimension \\
\hline Map & The indicator of specific location that have qualitative information \\
\hline Cartogram & Spatial map which has information that consist of location and qualitative data \\
\hline Photo-realistic picture & Realistic picture of an object \\
\hline
\end{tabular}

After the analysis of visual representation based on its function and category, comparison visual representation from three different publisher biology textbook is carried out.

\section{RESULT AND DISCUSSION}

Visual representation can become an important role in learning. Student can study more communicative because it is able to use with another representation like audio or text. This combination is usefully to reach learning targets and make student understand the learning material more easily [18].

Visual representaion which analyzed in this paper involve two categories. The are the function of visual representation and its modes categories. Based on analyses, results were showed in table 3 and figure 1 . Data were obtained as follows :

Table 3. Total and Percentage of visual representation based on its function that showed in biology textbook grade XI

\begin{tabular}{|l|l|l|l|l|l|l|l|l|l|}
\hline \multirow{2}{*}{$\begin{array}{l}\text { Biology } \\
\text { Textbook }\end{array}$} & \multicolumn{3}{|c|}{ Visual Representations Based Its Function } \\
\cline { 2 - 11 } & \multicolumn{2}{|c|}{ Decorative } & \multicolumn{2}{c|}{ Illustrative } & \multicolumn{3}{c|}{ Explanatory } & \multicolumn{3}{c|}{ Complementary } & \multirow{2}{*}{ Total } \\
\cline { 2 - 11 } & Total & $\%$ & Total & $\%$ & Total & $\%$ & Total & $\%$ & 2 \\
\hline A & 1 & $2 \%$ & 6 & $9 \%$ & 7 & $11 \%$ & 0 & $0 \%$ & $22 \%$ \\
\hline B & 1 & $2 \%$ & 11 & $17 \%$ & 20 & $31 \%$ & 2 & $3 \%$ & $52 \%$ \\
\hline C & 0 & $0 \%$ & 5 & $8 \%$ & 12 & $18 \%$ & 0 & $0 \%$ & $26 \%$ \\
\hline
\end{tabular}

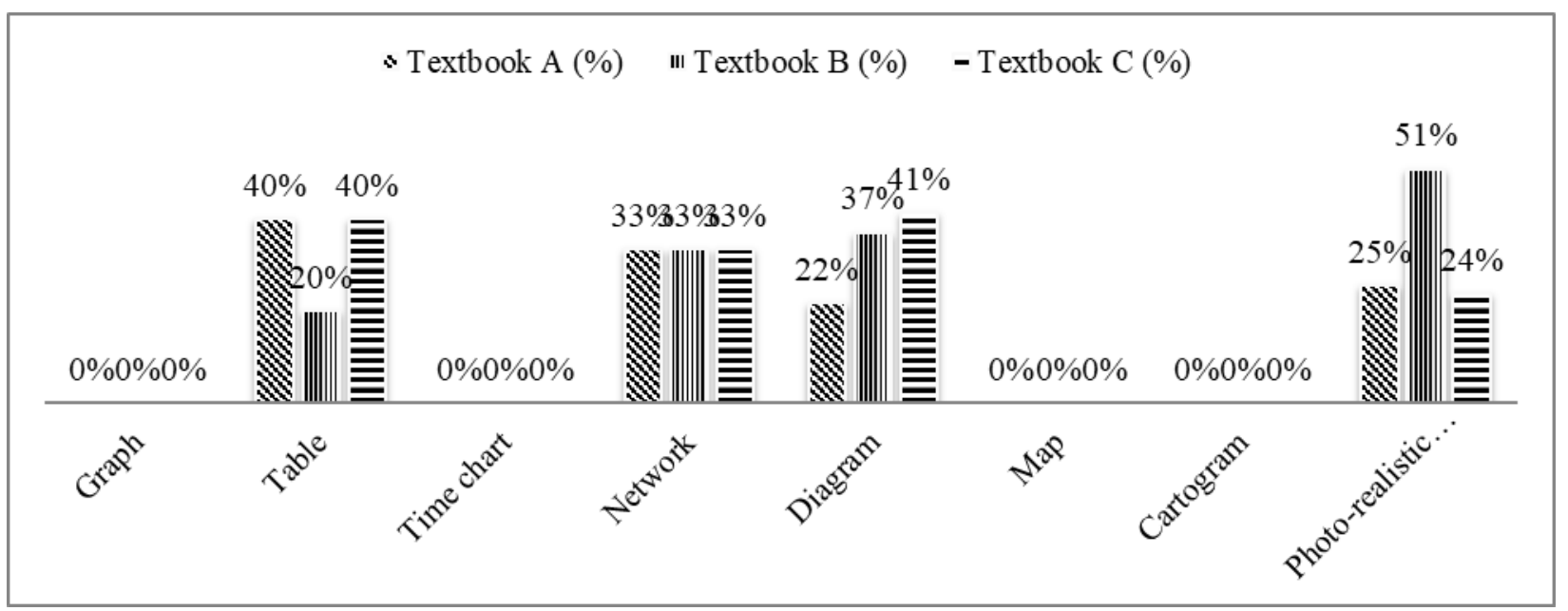

Figure 1. Visual Representation by Category

The result from analysis of visual representation based on its function in table 3 showed that decorative function found in textbook A $(2 \%)$ and B $(2 \%)$, but it doesn't exist in textbook C. Illustrative function was found most in textbook B $(17 \%)$ and at least in textbook $\mathrm{C}(8 \%)$. Explanatory function was found most in textbook B (31\%) and at least in textbook A (11\%). Complementary function was only found in textbook B 
(3\%) and it doesn't exist in another textbooks. The most visual representations showed in textbook B (52\%) and at least in textbook A $(22 \%)$. Based on the data, explanatory is the mostly found in textbooks if it compared with another functions. The complementary function only showed in textbook B. According to [19], complementary function makes learners have extensive experience in understanding visualization along with its information.

Based on result of visual representation that showed in biology textbook $\mathrm{A}$ is the least. According to [7] many visual representations are needed and recommended in biology textbook so that student can understand learning material easily. These because of visual representation in biology have important function to represent the relation with the main text.

Based on Figure 1, visual representations by category that was found in biology textbooks are table, network, diagram, and photo-realistic picture. Category table mostly found in textbook A (40\%) and C (40\%) and at least in textbook B (20\%). Category network that was found in textbook $\mathrm{A}, \mathrm{B}$, and $\mathrm{C}$ have same value $(33 \%)$. Category diagram mostly found in textbook $\mathrm{C}$ $(41 \%)$ and at least in textbook B (22\%). Category photo-realistic picture mostly found in textbook B $(51 \%)$ and at least in textbook C $(24 \%)$. Therefore, textbook A has higher value in category table, network, and diagram. Textbook $\mathrm{B}$ has higher value only in category photo-realistic picture. Textbook $\mathrm{C}$ has higher value in category table, network, and diagram. Category that mostly found in biology textbooks is photo-realistic picture $(51 \%)$.

Photos and text are related to each other when students read the science textbook. Photographs in Korean science textbooks can be added with inscriptions and text. Photos can be a source for linking tables, graphs, or formulas, on the one hand, and students' experiences in daily life [3].

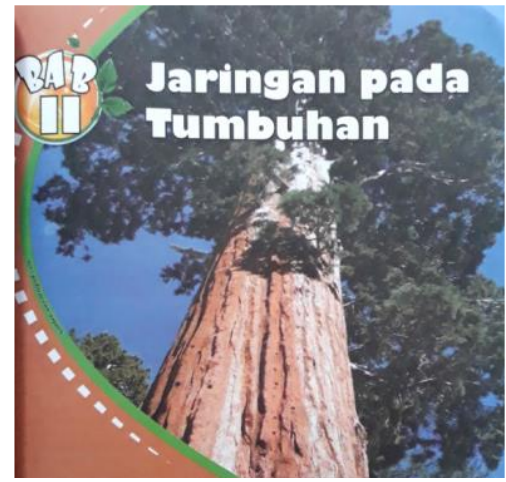

(a)

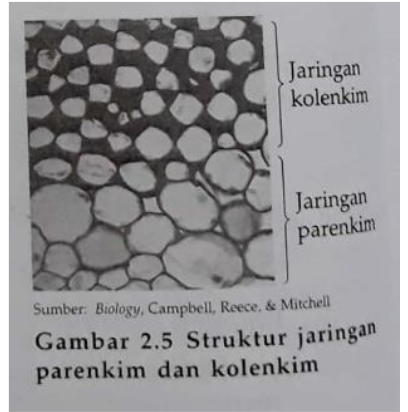

(b)

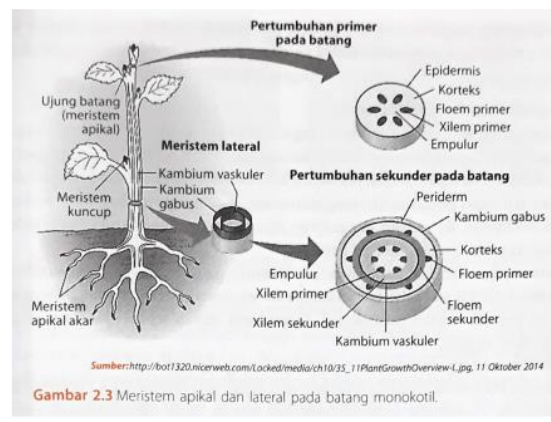

(c)

Figure 2. Visual Representations that showed in biology textbooks. Example for decorative function in textbook B (a), illustrative function in textbook A (b), and explanatory function in textbook $\mathrm{C}$ (c).

Generally, picture or visualization more preferable by brain compared with descriptive text and it can increase the student interest in reading. Picture can support the description of learning material that has been presented. Colored picture make the textbook more interesting and giving readers pleasure and comfort [20].

Textbook that showed colorless picture or visualization will be difficult for student to interpret. Interesting picture is needed for motivation student to study from textbook. Because of textbook can be a main teaching material or supplement that gives important role in learning [21].

Visual representation is part of physical representation which has purpose to enrich and sharpen human cognitive level. Visual representation in learning can help student to get knowledge from understanding picture or visualization. Using visual representation empirically in learning has been proven that it can support and help student to increase insight, knowledge, understanding, and transfer information which obtained [22].

Misinterpretation can be decrease with interpret many possibilities by means of visual representation. How the visual representation can increase student ability to create their diagram in designing experiment [23]. 
Teacher which has ability to integrate the visual representation's illustration characteristic can make it possible to interpret the meaning from visual representation. That is able to help teacher to know how far or how deep student can build concept of representation from submicroscopic level and symbolic which possible find simultaneously. Learning material can be obstacle in learning process if it has quite high level of difficulty. Therefore, teacher must be able to give instruction which needed by student. If explanation in textbook wasn't accompanied with visual representation which showed, teacher can give information verbally, because it is able to decrease student's difficulty in learning [24].

\section{CONCLUSION}

Based on analyses that has been done, the visual representations in three biology textbook in Indonesia according to its function explanatory is the mostly found in textbooks if it compared with another functions and complementary function only showed in textbook B. Visual representation based its function, decorative function was exist in textbooks A (2\%) and textbook B $(2 \%)$, illustrative function has the higher value in textbook B (17\%), explanatory function has the higher value in textbook $\mathrm{B}(31 \%)$, and complementary function only exist in textbook B (3\%). Visual representation that showed in biology textbook $\mathrm{A}$ is the least (22\%) and textbook B is the most (52\%). Visual representations by category that was found in biology textbooks are table, network, diagram, and photo-realistic picture. Textbook A has higher value in category table $(40 \%)$. Textbook B has higher value only in category photo-realistic picture (51\%). Textbook $\mathrm{C}$ has higher value in category table $(40 \%)$ and diagram (41\%). Each textbook has same value in category network $(33 \%)$.

\section{AUTHORS' CONTRIBUTIONS}

1,2 as the analyzer and the developer for this paper. All authorts are contributed in this paper.

\section{ACKNOWLEDGMENTS}

Authors would like to thank the anonymous reviewers for their cooperation and effort to make this paper better than before.

\section{REFERENCES}

[1] M. Sabirin, Representasi dalam pembelajaran matematika, JPM IAIN Antasari,2014, 1(2):33-44. DOI : http://dx.doi.org/10.18592/jpm.v1i2.49.

[2] P. Sinaga, I. Kaniawati, A. Setiawan, Improving secondary school students' scientific literacy ability through the design of better science textbooks, Journal of Turkish Science Education, 2017, 14(4):92-107. DOI : 10.12973/tused.10215a.

[3] W.M. Roth, L.P Ardenghi, Pictures in biology education, in: D.F. Treagust, C.Y. Tsui (Eds.) Multiple Representation in Biological Education, Springer, London, 2013, pp. 39-53. DOI : https://doi.org/10.1007/978-94-007-4192-8_3.

[4] B. Eilam, J. K. Gilbert, Teachers' use of visual representations in culturally-diverse classrooms, in: B. Eilam, J. K. Gilbert (Eds.), Science Teachers' Use of Visual Representations, Springer, London, 2014, pp. 145-147. DOI : https://doi.org/10.1007/978-3-319-06526-7.

[5] B.Waldrip, F. Rodie, Sutopo, The Implications of culture for teachers' use of representations, in: B. Eilam, J. K. Gilbert (Eds.), Science Teachers' Use of Visual Representations, Springer, London, 2014, pp. 145-147. DOI : https://doi.org/ 10.1007/978-3-319-06526-7 8.

[6] G. M. Ayu, Syarifuddin, Perbandingan keluasan, kedalaman dan kemutakhiran isi buku biologi SMA Indonesia dengan beberapa negara ain pada topik genetik, Jurnal Pelita Pendidikan, 2016, 4(1):91-98. DOI : https://doi.org/ 10.24114/ jpp.v4i1.3671.

[7] A. Mulyani, Representasi visual buku biologi SMA pada materi kingdom plantae, Scientiae Educatia, 2014, 3(1):35-47. DOI : http://doi.org/10.24235 /sc.educatia.v3i1.556.

[8] Suryani, E. Rudyatmi, T. A. Pribadi, Pengaruh experiential learning kolb melalui kegiatan praktikum terhadap hasil belajar biologi siswa, Unnes Journal of Biology Education, 2014, 3(2):220-228. DOI : https://doi.org/10.15294 /jbe.v3i2.4463.

[9] S. Limanto, R. Pramono, A. W Ristiyana, Aplikasi multimedia pembelajaran untuk meningkatkan minat belajar siswa terhadap materi struktur dan fungsi jaringan organ tumbuhan, Jurnal Informatika dan Sistem Informasi, 3(1), 2017, 4249. Retrivied from : http://repository.ubaya.ac.id 130076/13/Juisi.pdf.

[10] M. U. Kusumawati, S. Hidayati, Ratnawati, Identifikasi kesulitan belajar materi struktur-fungsi jaringan tumbuhan pada siswa SMA Negeri 3 Klaten kelas XI tahu ajaran 2015/2016, Jurnal Elektronik Pendidikan Biologi Indonesia, 5(7), 2016, 19-26. Retrivied from : http://journal. student.uny.ac.id/ojs/index.php/pbio/article/view/4 $627 / 4294$. 
[11] A. N. Halida, S. Windyariani, Meningkatkan motivasi dan kemampuan penguasaan konsep siswa pada materi struktur jaringan tumbuhan dan hewan melalui media biology quartet card, Jurnal Utile : Jurnal Kependidikan, 5(1) , 2019, 80-85. DOI : https://doi.org/10.37150/jut.v5i1.443.

[12] C. N. Syaputri, E. Djulia, Pengaruh model CIRC (cooperative integrated reading and composition) dengan menggunakan peta konsep terhadap hasil belajar siswa pada materi jaringan tumbuhan di kelas XI IPA SMA Muhammadiyah 1 Medan, Jurnal Pelita Pendidikan, 2018, 6(1):54-59. DOI : https://doi.org/10.24114/jpp.v6i1.9174.

[13] V. S. Elfada, E. Chandra, A. Mulyani, Analisis kualitas representasi visual buku biologi SMA kelas XI kurikulum 2013 pada materi sel, Scientiae Educatia : Jurnal Pendidikan Sains, 2015,4(2): 110. DOI : http://dx.doi.org/10.24235 /sc.educatia.v4i2.488.

[14] W. Sulistyowati, W. H. Omegawati, S. N. Hidayah, Buku Siswa untuk SMA/MA Kelas XI, Intan Pariwara, 2016.

[15] S. Prawirohartono, Konsep dan Penerapan Biologi SMA/MA Kelas XI Kelompok Peminatan IPA, Bailmu, 2017.

[16] Irnaningtyas, Y. Istiadi, Buku siswa biologi untuk SMA/MA Kelas XI, Erlangga, 2016.

[17] N. D. Ladue, J. C. Libarkin, S. R. Thomas, Visual representations on high school biology, chemistry, earth science, and physics assessment, Journal of Science Education and Technology,2015, 24(6):818-834. DOI : https://doi.org/10.1007/ s10956-015-9566-4.

[18] D.F. Treagust, C.Y. Tsui, Conclusion: contributions of multiple representation to biological education, in: D.F. Treagust, C.Y. Tsui (Eds.) Multiple Representation in Biological Education, Springer, London, 2013, pp. 39-53. DOI : https://doi.org/10.1007/978-94-007-4192-8.

[19] J. K. Gilbert, A. Afonso, Visualizations in Popular Books about Chemistry, in: B. Eilam, J. K. Gilbert (Eds.), Science Teachers' Use of Visual Representations, Springer, London, 2014, pp. 145147. DOI : https://doi.org/10.1007/978-3-31906526-7_10.

[20] M.S. Ami, E. Susantini, Raharjo, Pengembangan buku saku materi sistem ekskresi manusia di SMA/MA kelas XI, BioEdu, 012,1(2): 10-13. Retrivied from : https://jurnalmahasiswa. unesa.ac.id/index.php/bioedu/article/view/439.
[21] D. A. D. Kurniasari, A. Rusilowati, N. Subekti, Pengembangan buku suplemen IPA terpadu dengan tema pendengaran kelas VIII, Unnes Science Educational Journal, 2014, 3(2):462-467. DOI : https://doi.org/10.15294/usej.v3i2.3329.

[22] B. Eilam, Possible constraints of visual in biology : challenges in learning with multiple representation, in: D.F. Treagust, C.Y. Tsui (Eds.) Multiple Representation in Biological Education, Springer, London, 2013, pp. 39-53. DOI : https://doi.org/10.1007/978-94-007-4192-8_4.

[23] A.P. Dasgupta, T. R. Anderson, N. J. Pelaez, Development of the neuron assessment for measuring biology students' use of experimental design concepts and representatios, CBE-Life Science Education, 15(2), 2016, 1-21. DOI : https://doi.org/10.1187/cbe.15-03-0077.

[24] G. Papageorgiou, V. Amariotakis, V. Spiliotopoulou, Developing a taxonomy for visual representation characteristics of submicroscopic particles in chemistry textbooks, Science Education International, 2019, 30(3) : 181-193. DOI : https://doi.org/10.33828/sei.v30.i3.4. 